\title{
DERADIKALISASI SEMU: STRATEGI DERUTINISASI PENANGANAN SAMPAH ANALISIS STRUKTURASI DALAM ISU PENANGANAN SAMPAH DI KOTA BANDUNG OLEH WALIKOTA PERIODE 2013-2018
}

\author{
Mustabsyirotul Ummah Mustofa \\ Departemen Ilmu Politik, Universitas Padjadjaran \\ E-mail: mustabs.mails@gmail.com
}

\begin{abstract}
ABSTRAK
Penelitian ini dilatarbelakangi oleh kondisi Bandung sebagai lokus penelitian menangani masalah sampah yang cukup penting. Bahkan Bandung yang pernah dijuluki sebagai "kota sampah". Upaya untuk menangani sampah telah dicoba sejak walikota sebelumnya dengan cara radikal dan itu dengan mengubah sudut pandang limbah dengan melihat sampah sebagai sumber daya yang berharga. Namun upaya ini telah menemui jalan buntu dan bahkan menyebabkan konflik. Walaupun upaya derutinitas tentang pengelolaan limbah belum mengkristal sepenuhnya, pada dasarnya walikota menyiapkan modal yang lebih memadai dan struktur pendukung. Walikota membuat seolah-olah upaya deradikalisasi adalah strategi untuk membentuk ibukota dengan tujuan untuk pengelolaan limbah derutinitas nyata. Ini bertujuan untuk mendapatkan sumber daya dari struktur jejak bahwa dia telah dibuat, dalam bentuk dukungan publik yang akan membantu untuk memiliki radikalisasi ditunda agenda sampah, yang tujuan radikalisasi nyata pada dasarnya adalah sebuah kota yang bersih dengan pengelolaan sampah modern melalui penggunaan teknologi. Fenomena ini telah menandai bahwa reproduksi infreastruktur baru adalah proses yang panjang dan rumit serta membutuhkan banyak prasyarat untuk mencapai tujuan derutinitas.
\end{abstract}

Kata kunci: jejak struktural, radikalisasi, derutinitas, dualitas struktur

\section{PSEUDO-DERADICALIZED: DERUTINENESS AS WASTE MANAGEMENT STRATEGY (STRUCTURATION THEORY ANALYSIS ON WASTE MANAGEMENT ISSUE IN BANDUNG BY THE MAYOR OF THE 2013-2018 PERIOD)}

\begin{abstract}
This research is motivated by the condition of Bandung as the locus of research addressing the issue of waste, that is quite crucial, even Bandung has ever dubbed as "the city of pig" and "the city of waste". The efforts to deal with the waste have been tried since the previous Mayor with radical way and that was by changing the viewpoints of waste by viewing the waste as valuable resources. But this effort was been deadlocked and even causing a conflict. Eventhough the deroutineness efforts on waste management has not been fully crystalized, basically the Mayor is on progress preparing more adequate capital and supporting structure. The Mayor makes as if the deradicalization efforts is a strategy to form capitals as a mean for real deroutineness waste management. This aims to get resources from the structure traces that he's been created, in the form of public support that will help to have the postponed radicalization of waste agenda, which the real radicalization objective is essentially a clean city with modern waste management through the use of technology. This phemenon has marked that the reproduction af a new structure is a long and complicated process and requires a lot of precondition to reach the deroutineness goal.
\end{abstract}

Keywords: Structural traces, radicalization, deroutineness, the duality of structure 


\section{PENDAHULUAN}

Cerita ini dimulai dari awal tahun 2014 lalu, Bandung digegerkan oleh sebuah tulisan seorang warga Bulgaria, Inna Savova, dalam blognya menyebut Bandung sebagai "The City of Pigs" . Olok-olok ini tentu saja berbeda dengan janji atau kehendak pemerintah. Melalui Perda No. 08 Tahun 2008 tentang RPJPD Kota Bandung Tahun 2005-2025 disebutkan bahwa Bandung mengusung sejumlah misi, salah satunya adalah menatanya "Menuju Metropolitan Terpadu yang Berwawasan Lingkungan". Dari segi persampahan, Bandung bertekad untuk "Mewujudkan Pengelolaan Limbah Padat yang Efektif dan Bernilai Ekonomis".

Olok-olok tersebut merupakan cerita panjang dari perjalanan Bandung menangani sampah pasca bencana longsor TPA Leuwigajah pada tanggal 21 Februari 2005 hingga menimbulkan korban jiwa yang menjadi titik balik persoalan krusial sampah. Pasca bencana longsor tersebut, dalam kurun waktu lama tidak ada Tempat Pembuangan Akhir (TPA) sampah. Upaya pencarian TPA pengganti memang sudah dilakukan oleh pemerintah, beberapa daerah sempat dijadikan TPA (yaitu Jelekong, Cicabe, Cikubang, dan yang terakhir Sarimukti), namun semuanya hanya bersifat sementara karena keterbatasan kapasitas lahan (Saragih, 2013: 104). Mau tidak mau, Pemerintah Kota Bandung harus bertindak cepat mengatasi persoalan sampah karena setiap hari volume sampah di Kota Bandung terus bertambah. Sebagai catatan, timbunan sampah yang ada di Kota Bandung mencapai 1500 ton sampah perharinya, dan yang dapat diangkut oleh PD Kebersihan hanya 1100 ton. Sampah yang dikelola masyarakat 200 ton dan sekitar 200 ton sampah belum bisa diangkut di TPS-TPS ${ }^{2}$. Hal ini menunjukkan bahwa persoalan sampah di Kota Bandung sudah dianggap sebagai persoalan publik yang penting yang perlu mendapat penanganan serius dari pihak pemerintah untuk mencari solusi startegis dari permasalahan publik tersebut.

Upaya untuk keluar dari kendala stuktural hendak dicoba dengan mengandalkan teknologi. Pemerintah Kota Bandung sejak walikota periode 2008-2013 mencangankan

http://venusgotgonorrhea.wordpress.com/2014/01/16/bandung-thecity-of-pigs/ (diakses pada hari Senin, 29 September 2014)

2 Persoalan Sampah Makin Menghantui Warga". Majalah Swara Bina Kota. Edisi 1/2014. Halaman 40. pengolahan sampah dengan menjadikannya PLTSa (Pembangkit Listrik Tenaga Sampah) di wilayah Gedebage Bandung, dengan harapan bahwa sampah warga kota dapat menjadi manfaat untuk membangkitkan listrik di area seluas 20 hektare. Namun hingga pergantian walikota yang baru periode 2013-2018, saat ini PLTSa tidak ada realisasi yang berarti, meskipun DPRD Kota Bandung telah mengesahkan kelanjutan dari PLTSa. Hal ini dikarenakan rencana melanjutkan proyek PLTSa mendapat tantangan dari Pegiat lingkungan (NGO) dan warga sekitar wilayah Gedebage termasuk budayawan di Kota Bandung. Hingga saat ini Pemerintah Kota belum banyak merespon pihak-pihak yang berkepentingan. Walikota di satu sisi menjadi harapan masyarakat untuk dapat menyelesaikan masalah sampah ini. Disisi lain Walikota dihadapkan dengan $\mathrm{MoU}$ pihak ketiga perusahaan pemenang tender dan hasil kesepakatan DPRD Kota Bandung yang mengisyaratkan bahwa proyek PLTSa ini harus dilanjutkan. Ditengah menggantungnya proyek PLTSa dan gugatan-gugatan kelompok masyarakat yang kahwatir akan tetap berjalannya proyek tersebut, Walikota baru justru membuat proyek-proyek lain dalam hal penanganan sampah.

Berdasarkan uraian latar belakang, penelitian ini ditujukan untuk menjawab pertanya-an: Mengapa Walikota memilih strategi deradikalisasi dalam upaya derutinisasi penanganan sampah di Kota Bandung?

Penggunaan teori strukturasi dalam penelitian ini dikarenakan isu sampah yang sudah lama menjadi problematika public dan didalamnya sarat dengan suasana konflik. Dalam strukturasi, konflik yang terjadi lebih sering disebut dengan kontradiksi, ketika adanya konsekuensi yang tidak diharapkan muncul akibat tindakan para agen. Kondisi pemicu konlik ini ditemui dalam hubungan antara kontradiksi dengan kepentingan bersama. Hal ini terjadi akibat perbedaan sudut pandang mengenai makna sampah di mata masyarakat. Perbedaan agen dalam memandang "sampah", tidaklah harus digeneralisir dengan kacamata yang sama. Agen memiliki pengetahuannya sendiri yang akhirnya membentuk konsepsi tentang sampah, karena agen cenderung menjadi aktor yang aktif dan kreatif dalam memenuhi kebutuhan jasmaniahnya sendiri maupun terlibat dalam 
perilaku secara terus menerus dalam rangka mengatasi masalah persampahan (Ritzer dan Goodman, 2004).

Merevolusi ulang pemaknaan sampah pada akhirnya menjadi agenda penting untuk mendudukkan sampah sebagai bagian dari dimensi signifikansi. Struktur signifikansi menyangkut skemata simbolik, pemaknaan, penyebutan dan wacana dan oleh karenanya harus selalu dipahami dalam kaitannya dengan dominasi dan legitimasi karena memiliki pengaruh kuat dalam kehidupan sosial dan jika dipisahkan masingmasingnya justru meniadakan struktur secara utuh (Giddens, 2010). Wacana sampah yang dipahami berbeda tentunya akan mengakibatkan pertentangan dalam dimensi struktur lainnya yakni legitimasi dan dominasi. Dominasi sendiri merupakan kondisi keberadaan kode-kode signifikansi yang berkaitan dengan autorisasi dan alokasi sumber daya (sampah), begitu juga dengan legitimasi yang muncul yang merupakan bentuk regulasi normatif soal persampahan yang memiliki kekuatan mengikat seluruh elemen masyarakat.

Dualitas struktur dan agensi selalu merupakan landasan utama bagi keterulanganketerulangan dalam reproduksi sosial di sepanjang ruang waktu yang pada gilirannya membutuhkan kemampuan mawas diri dan instropeksi (reflexive monitoring) dari para agen sebagai pembentuk aktivitas sosial sehari-hari. Menurut Giddens bahwa "struktur hanya ada di dalam dan melalui aktivitas agen manusia", menunjukkan bahwa struktur merupakan medium sekaligus hasil dari tindakan yang ditata secara berulang oleh struktur. Ditekankan pula tentang 'keterinformasian' aktor yang tergantung pada pengetahuan dan strategi yang ada untuk meraih tujuan produksi atau reproduksi (Nashir, 2012).

Giddens mengungkapkan "structure thus is not to be conceptualised as a barrier to action but as essentially involved in its production" (Giddens, 1979), yang bermakna bahwa struktur dapat menjadi penghambat (constraining) atau pemberdaya (enabling) dalam proses strukturasi. Hal ini dimungkinkan karena 'constraining' ataupun 'enabling'-nya struktur bagi 'agency' dipengaruhi pula oleh kondisi dan kepentingan pelaku (Haryanto, 2009). Hambatan sendiri berkaitan erat dengan sifat-sifat struktural. Hambatan tidak 'mendorong' siapapun (agen) untuk melakukan sesuatu jika agen masih belum merasakan ke-usang-an struktur. Dan dalam kesadaran agen terhadap adanya hambatan tersebut maka akan lebih mudah untuk menyiasati struktur yang mana mengindikasikan bahwa struktur juga memberdayakan.

Selain sifat struktur yang bisa jadi menghambat atau memberdayakan, dalam upaya reproduksi sosial, Hay dan Jossep membaca dualitas struktur dan agensi dengan pendekatan kunci yakni strategi, yang menekankan kemampuan agen untuk mengubah keadaan struktural melalui sebuah proses aktif pembelajaran strategis. 'Agen' adalah mawas diri, mampu merumuskan ulang dalam batas-batas identitas dan kepentingan mereka sendiri, dan mampu melakukan perhitungan strategis tentang situasi mereka saat ini'. (Marsh \& Stoker, 2011 : 337). Namun penerapan strategi sebagai kunci yang diterapkan dalam relasi ini memiliki dampak tersendiri dimana strategi yang digunakan oleh aktor tertentu akan berdampak pada aksi atau sistem tertentu pula. Artinya, dalam penerapan strategi, pilihan-pilihan rasional dengan kesadaran dan pengetahuan melingkupitindakan dari agensi.

\section{METODE}

Penelitian ini merupakan penelitian kualitatif yang menggunakan metode studi kasus. Penggunaan metode studi kasus sendiri berangkat dari kerangka pemikiran agenstruktur yang digunakan yang bertujuan untuk menghubungkan tindakan-tindakan aktor-aktor dan posisi struktur yang menghambat atau memberdaya proses penanganan persoal-an sampah di Kota Bandung serta menganalisis upaya derutinisasi penanganan sampah. Setting penting dalam penelitian ini adalah upaya derutinisasi dan dualitas struktur yang terjadi dalam penanganan sampah di Kota Bandung. Oleh karena itu, dalam penelitian ini dibutuhkan beragamjenis sumber data yang dapat membuka lapisan-lapisan wacana yang timbul dalam penanganan sampah yakni studi dokumentasi, analisis semiotika dan wawancara mendalam.

\section{HASIL DAN PEMBAHASAN}

\section{Pilihan Strategis Derutinisasi}

Ada empat hal yang menjadi penanda bahwa yang dilakukan oleh Walikota adalah 
upaya derutinisasi yang terkesan melakukan deradikalisasi penanganan sampah berbanding terbalik dengan upaya radikalisasi sampah pada Pemerintahan sebelumnya. Pertama, soal tertib buang sampah. Jika pada pemerintahan sebelumnya, agenda menertibkan kebiasaan masyarakat buang sampah pada tempatnya menjadi agenda yang tidak begitu penting bagi Pemkot sekalipun, aturan nomatifnya sudah dipersiapkan di Perda No. 11 Tahun 2005 tentang Penyelenggaraan Ketertiban, Kebersihan dan Keindahan alias Perda K3. Pada masa Walikota lama, tidak ada optimalisai penegakkan Perda K3, karena berfokus pada penyelesaian masalah jumlah timbulan sampah dengan teknologi insenerator (PLTSa). Terpusatnya perhatian Pemkot lama pada PLTSa justru mengabaikan unsur masyarakatnya sebagai produsen sampah dan malah membuka masalah baru dengan adanya konflik. Ridwan Kamil melihat kecenderungan ini akan menimbulkan masalah baru apabila Pemkot tetap bersikukuh mempertahankan PLTSa dan beralih pada penanganan sampah dengan penegakkan Perda K3 guna mencapai tujuan kota bersih seperti cita-citanya.

Kedua, menggulirkan wacana pembubaran PD Kebersihan dan menggantinya dengan Dinas Kebersihan. Gagasan ini menjadi salah satu indikator penting deradikalisasi yang diciptakan oleh Walikota. Bagi Pemerintahan sebelumnya sudah memandang sampah sebagai komoditas yang menghasilkan PAD. Cara pandang ini juga tidak hadir tiba-tiba melainkan dikonstruksi oleh situasi donor Bandung Urban Development Project. Ridwan Kamil memilih mengembalikan bentuk BUMD ke Dinas dengan alasan efisiensi dana dan optimalisasi pelayanan persampahan. Hal ini didasari fakta bahwa PD Kebersihan selalu merugi setiap tahun dan tidak membiayai dirinya sendiri. Ada kesan yang diciptakan, bahwa tidak peduli soal PAD dari sampah yang bisa dihasilkan, tapi yang terpenting bagi Walikota adalah bagaimana pasukannya (SKPD) dapat optimal mendukung perencanaannya menuju Bandung Juara Bebas Sampah, Kota Bersih dan Kota Modern.

Ketiga, mengganti PLTSa dengan Biodigester secara massif. Dalam perhitungan ekonomi Pemerintah, PLTSa tentunya sudah dikalkulasi akan membawa keuntungan bagi Pemkot Kota Bandung. Namun Ridwan Kamil menyadari bahwa PLTSa bisa menjadi polemik yang akan berkepanjangan dan menyandra dirinya. Hal inilah yang menjadi alasan Walikota memilih biodigester yang menjadi alternatif pengelolaan waste to energy yang menjadi amanat dalam RPJMD maupun RPJP Kota Bandung. Biodigester secara hitung-hitungan dipilih untuk meminimalisiri resiko lingkungan dan dampak sosial yang ditimbulkan karena biodigester dicanangkan untuk ditempatkan di setiap Rukun Warga. Selain itu Biodigester juga memenuhi harapan para pegiat lingkungan untuk pengelolaan sampah yang terdesentralisasi. Pilihan Biodigester tidak akan memberikan masukan langsung terhadap PAD, tapi biodigester mampu memberikan sumber daya dukungan bagi Ridwan Kamil, terlebih banyak pihak swasta yang dilibatkan dalam pengadaan Biodigester dengan mekanisme CSR.

Keempat, mengubah pengelolaan sampah dari pelayanan ke tanggung jawab bersama. Pergeseran struktur legitimasi persoalan sampah ari pelayanan ke tanggung jawab bersama menjadi salah satu upaya derutinisasi yang dilakukan. Hal ini bertujuan untuk sharing beban masalah publik kepada masyarakat dan swasta. Tampak bahwa Ridwan Kamil masih belum mempedulikan sampah secara profit, tapi yang jelas sampah harus jadi masalah bersama. Bagi Ridwan Kamil misalnya, perilaku membuang sampah sembarangan adalah sebuah masalah serius. Ada kesadaran bahwa dalam mencapai keberhasilan tidak bisa berjalan sendiri. Kesadaran ini dipengaruhi oleh paradigm governance yang mau tidak mau menjadi pilihan dari setiap pemangku kebijakan untuk dijalani. Intinya Ridwan Kamil sedang menciptakan social order, mengganti makna pelayanan ke makna tanggung jawab. Hal ini senada dengan wacana yang ditawarkan Pardo (1997) dalam mengatasi persoalan sampah adalah dengan menghadirkan tawarantawaran pemecahan masalah yang juga bersifat struktural, dengan pendekatan agama, moral, estetika, dan kesehatan, yang pada intinya menciptakan social order mengenai apa yang baik dan buruk.

Pilihan-pilihan ini menjawab identifikasi persoalan sampah dari level partisipasi masyarakat yang ternyata sangat diperlukan perbaikan dalam beberapa aspek, yakni: a) Peningkatan pengetahuan akan masalah sampah dan kaitannya dengan kesehatan lingkungan; 
b) Partisipasi yang dituntut dari masyarakat oleh Pemda dalam pengelolaan persampahan kota, yaitu antara lain dalam pewadahan sampah dirumah masing-masing atau di TPS/BaK Umum, dan dalam pengumpulannya hingga terkumpul di penampungan sementara (TPS); c) Pentingnya membayar retribusi kebersihan, oleh warga-warga dan penjelasan sistem tarif yang akan diterapkan, dimana disesuaikan dengan kegiatan yang banyak menghasilkan sampah atau terhadap tingkat pendapatan Rumah Tangga: dan d) Masyarakat berperan serta dalam melakukan pengurangan sampah dengan cara $3 \mathrm{R}$ diantaranya bank sampah dan juga pengomposan ${ }^{3}$. Keempat aspek tersebut sebenarnya merupakan identifikasi persoalan yang dianalisis oleh para pegiat lingkungan dan para akademisi yang banyak bersebrangan dengan program-program Walikota. Namun sedikit banyak upaya derutinisasi yang dilakukan Walikota mengakomodir solusi tersebut. Muaranya kembali lagi pada kesadaran masyarakat bahwa sampah merupakan permasalahan bersama.

Pendekatan umum yang dilakukan dalam menyelesaikan masalah persampahan adalah pendekatan yang konvensional yang bersifat pasif dan instruksional dengan lebih menekankan pada penanganan dan pengelolaan sampah yang dibuang (end-off pipe approach). Kebijakan pengelolaan sampah lebih menekankan pada bagaimana sampah dikumpulkan, diangkut, dan dibuang karena dianggap sebagai barang sisa (Gertsakis dan Lewis, 2003). Sementara, menelisik lebih dalam tapak-tapak tatanan struktural yang sedang dibangun, Walikota sedang bermimpi untuk membangun sebuah peradaban kota yang menyenangkan dengan identitas sebagai 'kota bersih', dilihat dari penggunaan indikator keberhasilan pembangunan kota yang tidak bersifat teknis, disebut-sebut sebagai Indikator Pembangunan Kota Masa Depan yang terdiri dari Green City, liveable City, serta Smart City, maupun indeks kebahagiaan ${ }^{4}$. Artinya indikator bertumpu pada persepsi manusia sebagai objek penting yang ada dalam ruang kota.

Pilihan kebijakan yang diambil nyatanya secara sadar dipengaruhi oleh pengetahuan agensi tentang pembangunan peradaban kota. Dalam penjelasan diskursifnya, di teori tata kota,indikator kebahagiaan itu semakin banyak ${ }^{3}$ Dokumen Masterplan Persampahan Kota Bandung 2013

${ }^{4}$ Dokumen RPJMD Kota Bandung 2013-2018. manusia berinteraksi, semakin bahagia. Oleh karenya nya event-event perjumpaan, seremonial, seperti arisan, pengajian, bertemu di jalan, nongkrong di kafe, nongkrong di trotoar, jalanjalan ke taman, akan memperbesar persentase interaksi manusia dengan manusia lain yang mengakibatkan Indeks happiness nya naik. Prinsip ini Ia gabungkan dengan prinsip urban planning, yang mengarah pada kota masa depan, indikatornya adalah pemanfaatan teknologi dan infrastruktur yang menunjang peradaban kota modern ${ }^{5}$. Maka menjadi relevan apabila Walikota masih mempertahankan penanganan sampah dengan tradisi end-off pipe dan melakukan rekayasa sosial dengan membentuk kesadaran tertib membuang sampah sebagai bagian dari membangun rasa tanggung jawab bersama.

Wacana membangun peradaban kota menjawab, mengapa pada program-program penanganan sampah yang dipilih oleh Walikota merupakan program-program yang bersifat seremonial, populis dan berupa hiburan. Gagasan ini lahir dari kesadaran bahwa persoalan sampah kota bukan persoalan yang sifatnya teknis. Walikota memilih cara-cara yang bagi sebagian besar dianggap populis sebagai cara menyampaikan maksud membangun peradaban kota. Pemikiran soal estetika sebagai 'kota bersih' hanya bisa lahir dari penghayatan terhadap kebudayaan. Para budayawan sepakat bahwa sampah merupakan wajah kota. Penghayatan yang tinggi terhadap keharmonisan ekosistem lingkungan dan manusia bisa jadi melekat dalam kesadaran praktis Walikota, namun dari teks ini memberitahu kita secara langsung bahwa tindakan-tindakan yang dilakukan oleh agen, dikendalikan oleh wacana yang berada diluar kuasa agensi, yang berasal dari penasehat utama Walikota, yang merupakan seorang budayawan. Penetrasi wacana yang dilakukan oleh tim ahli merupakan bagian dari interaksi struktur dan agen. Kesadaran bahwa pengelolaan sampah kota merupakan hal yang kompleks ditambah dengan adanya rutinitas pertemuan yang kontinyu antara Walikota dan Tim ahlinya, mempengaruhi kesadaran praktis agensi. Hal ini pula yang menjadi alasan mengapa wacana yang disodorkan oleh NGO tidak semua diakomodir dalam implementasi kebijakan penanganan sampah karena dianggap wacananya terlalu bersifat teknis.

\footnotetext{
Wawancara Ridwan Kamil \#205BDG dan Mimpi Bandung Juara, 26 September 2015 http://www.rappler.com/indonesia/107170-wawancara-ridwan-kamil-mimpi-bandung-juara
} 


\section{Deradikalisasi Sampah Sebagai Komoditas Politik}

Kepentingan para aktor yang terlibat dalam politik sampah menjadi fokus penting yang diungkapkan di beberapa penelitian, misalnya, dalam penelitian Kota Spokane (AS) oleh Larry S. Luton (1996) dan di Irlandia oleh Honor Fagan (2003). Dalam penelitian tersebut, kepentingan masing-masing aktor menjadi penentu dalam pembuatan kebijakan penanganan sampah dengan melihat beragam perspektif soal penanganan sampah, serta bagaimana beragam perspektif tersebut dimenangkan dalam bentuk kebijakan. Perbedaan perspektif ini dipengaruhi oleh budaya politik masyarakat setempat dan isu lokal dan internasional soal sampah yang dibawa oleh media. Selain itu, perbedaan juga soal latarbelakang ideologi dari setiap aktor yang berbeda. Dalam teori strukturasi, fokus kepentingan aktor dalam pewacanaan sampah dianggap tidak bisa berdiri sendiri. Analisis aktor dalam strukturasi merupakan analisis dimensi internal agensi yang mencakup kesadarn diskursif, kesadaran praktis dan motivasi tak sadar aktor yang tercermin dalam tindakan-tindakan agensi. Baik kepentingan, perspektif dan ideologi, dibaca dalam frame kesadaran praktis.

Dalam penelusuran, penelitian ini menemukan bahwa deradikalisasi semata-mata adalah sebuah strategi derutinisasi mengingat banyak sekali lapis-lapis dimensi dalam menangani persoalan sampah. Kendala-kendala struktural penanganan sampah yang ada di Bandung merupakan persinggungan antara berkah dan petaka. Berkah berarti sampah sebagai komoditi yang membawa keuntungan bagi banyak pihak yang paham, sementara petaka menghantui manakala salah langkah dalam menangani sampah dan menimbulkan konflik baru ditengah banyaknya pihak yang kontra. Ridwan Kamil tetap merupakan agensi yang berpikir instrumental bagaimana menambah nilai pada benda (sampah). Hal ini merupakan kesadaran diskursif yang melekat dalam knowledge abilitynya sebagai seorang urban planner.

Gambar curhatan Walikota yang diunggah di media sosial ini sebenarnya memberi jawaban mengapa pilihan radikalisasi dikesampingkan. Banyak tantangan yang harus dihadapi jika Walikota tetap bersikukuh dengan program para NGO dan Pemkot lama yang mengubah cara pandangmasyarakatbahwasampahadalah sebuah sumber daya. Pilihan melakukan deradikalisasi pun memiliki tantangan yang sama sulitnya, yakni menghadapi protes warga, anggaran yang tidak memadai, tim yang tidak kompeten, serta regulasi yang menghambat. Hanya saja ada kesadaran bahwa jika memaksakan radikalisasi dan melanjutkan program Pemkot lama soal PLTSa atau mengakomodir kemauan para pegiat lingkungan soal desentralisasi yang terjadi adalah penolakkan dari masyarakat yang lebih besar. Sementara yang dibutuhkan oleh Walikota adalah kondisi kondusif yang memberi dukungan terhadap apapun yang akan ia lakukan dalam memoles Bandung. Yang Walikota lakukan ternyata melakukan radikalisasi secara merambat dengan terlebih dulu menyiapkan modalitas untuk mencapai struktur signifikansi yang baru, yakni dengan perlahan mengubah kebiasaan masyarakat untuk tertib membuang sampah dan menjadikan sampah sebagai persoalan bersama.

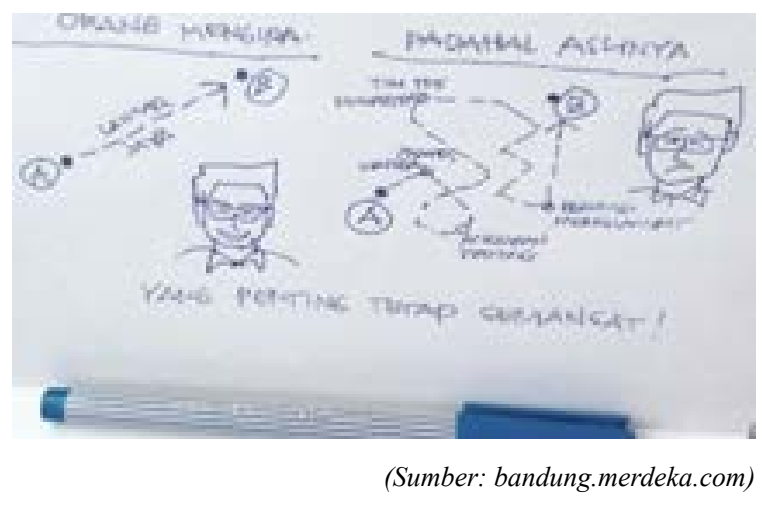

Gambar 1. Tanggapan Ridwan Kamil Terhadap Kritik Mengenai Dirinya

Bagi Walikota, dibutuhkan cara untuk mempertemukankesadaran lingkungan, normalitas nyampah dan kebutuhan ekonomi manusia. Nyatanya kesadaran diskursif ini merupakan konstruksi governance dalam pengelolaan sampah yang berlaku hampir di seluruh Negara, sesuai dengan kesepakatan dan instruksi dari UNEP (United Nation Environment Programme). Konstruksi global ini yang tidak bisa ditolak oleh Pemerintah manapun dalam pengelolaan sampah.

Jadi yang terbentuk seolah-olah Walikota sedang menghindari wacana penanganan sampah yang njlimet dengan memilih wacana yang aman yang mampu dikerjakan, padahal Walikota sedang menyiapkan instrument (dalam bahasa strukturasi disebut dengan modalitas) yang 
mampu memuluskan upaya radikalisasi dengan melibatkan lebih banyak swasta. Kata kuncinya ada pada 'kepentingan manusia di Negaranegara yang sedang membangun'. Kredo kolaborasi yang dikampanyekan oleh Walikota membuka ruang keterlibatan swasta secara aktif dalam penanganan sampah. Ditambah cita-cita Walikota untuk menciptakan peradaban kota Bandung yang modern, yang masih membutuhkan tatanan pembangunan fisik. Buktiyang paling konkrit adalah pelibatan swasta dalam pengadaan Biodigester baik skala rukun warga maupun biodigester dalam skala lebih besar untuk pengelolaan sampah pasar yang sudah selesai di bangun di Pasar Induk Gedebage.

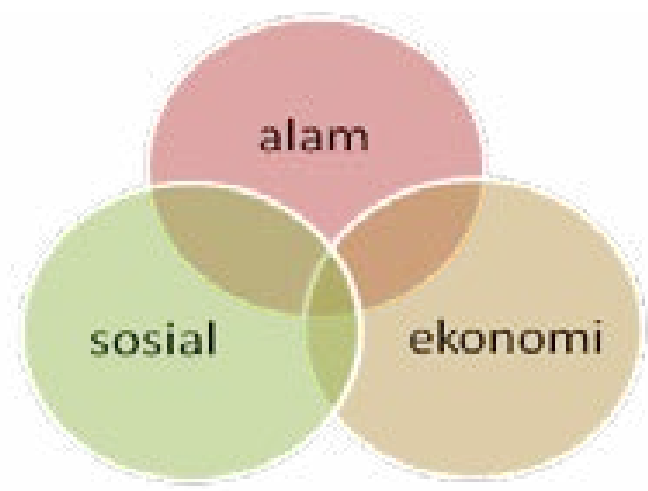

Gambar 2. Paradigma Pengelolaan Lingkungan

Dalam paradigma govenance, tentunya hal ini merupakan praktik yang baik yang dilakukan oleh Pemerintah Kota Bandung. Namun, hal ini menjadi ruang terbuka bagi swasta untuk melakukan eksploitasi atas nama pembangunan kota. Hal ini dibuktikan dengan eratnya hubungan Walikota dengan pihak swasta, dimana mayoritas program dibiayai oleh dana CSR perusahaan. Pertanyaannya, apakah CSR diberikan secara cuma-cuma? Isu terbaru saat ini terkait dengan pembangunan Kawasan Bandung Technopolis, dengan developer skala nasional, yakni Summarecon yang sudah dilaunching November 2015 kemarin. Tentu saja rencana ini ditentang keras oleh para pegiat lingkungan, karena mengambil lahan sawah abadi yang berada di kawasan Bandung Timur. Tuduhan WALHI, Walikota sudah menyalahi peran dan fungsinya karena bertindak sebagai promotor dari Summarecon, jauh dari yang dibayangkan oleh para pegiat lingkungan bahwa Walikota akan menjadi garda terdepan mengawal lingkungan Kota Bandung ${ }^{6}$.

\footnotetext{
${ }^{6}$ Wawancara dengan Direktur WALHI Jabar, Dadan Ramdan, pada 28 November 2015
}

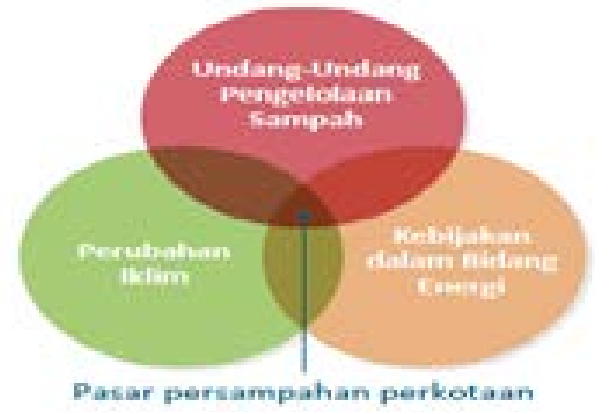

(Sumber: Butler, 2013)

Gambar 3. Dorongan Kebijakan yang Mendukung Pengembangan Proyek Persampahan Perkotaan Secara Komersial

Walikota terlihat sangat kompromistis dengan pihak swasta. Dalam jawaban Tim Ahli, bahwa budaya kompromistis adalah sebuah kebijaksaan. Hal ini merupakan salah satu falsafah dalam kebudayaan sunda yang disebut dengan 'singer' atau 'sigar tengah', yang artinya bertindak seimbang dan tidak memihak. Walikota tidak mungkin selamanya mengakomodir keinginan NGOs yang beragam. Tujuantujuan pembangunan harus juga dilaksanakan dan jalan tengahnya adala bekerjasam dengan pihak sawasta. Niatnya adalah merangkul semua kalangan dalam melakukan tindakan seperti dalam babasan 'caina herang, laukna beunang' (airnya jernih, ikannya dapat) ${ }^{7}$. Jadi tidak heran kalau Walikota banyak bekerjasama dengan pihak swasta untuk meraup CSR yang digunakan sebagai sumberdaya menambah kapasitas transformatifnya.

Wacana tentang lingkungan dan pembangunan berkelanjutan pada dasarnya berbicara tentang akses, kontrol, pemanfaatan alam oleh manusia serta implikasi-implikasinya. Yang ditunjukkan oleh Walikota pun, nyatanya sedang berbicara akses dan kontrol. Akses terkait dengan dominasi alokatif yang dimiliki Walikota dan kontrol yang merupakan dominasi otoritatif. Sehingga, strategi dan kuasa pengetahuan agensi menjadi energi penting untuk bisa menghindari dominasi struktur sehingga memungkinkan agensi melakukan dialektika untuk mereproduksi struktur (Kurniawan, 2012: 14).

Terlepas dari isu yang berkembang, soal keter-libatan aktif swasta dalam penanganan sampah, nyatanya manajemen sampah saat ini menjadi ladang bisnis baru yang menjanjikan, terutama dalam hal investasi teknologi pengelolaan sampah. Tidak bisa dipungkiri lagi bahwa

\footnotetext{
${ }^{7}$ Wawancara dengan Budaywan Aat Suratin, 26 November 2015
} 
penangan sampah membutuhkan bantuan teknologi karena kemampuan manusia mengelola sampah tidak sebanding dengan produksi sampah yang dihasilkan setiap harinya.

Referensi di Negara-negara maju sudah sampai pada tahap kesadaran soal kebersihan dan pengelolaan sampah yang modern. Tentunya sebagai urban planner, tidak akan melewatkan tujuanini. Hanyasajajalan yang dipilihmerambat dibanding harus melompat-lompat tanpa disertai modalitas. Modalitas yang paling dirasa penting adalah dukungan publik, oleh karenanya terlihat sekali kebijakan-kebijakan populis demi meraih kapasitas transformatif. Struktur dukungan publik ini yang dipercaya menjadi sumber daya pembentukan sarana lainnya seperti regulasi, yakni bagaimana memuluskan keterlibatan swasta demi kemajuan pengelolaan sampah, seperti yang dikatakan Ridwan Kamil bahwa masalah akan selesai dengan kolaborasi dari Pemerintah, masyarakat, kapital dan media ${ }^{8}$.

Maka pada dasarnya deradikalisasi yang dilakukan bukanlah deradikalisasi pada kenyataannya (deradikalisasi semu). Deradikalisasi hanya sebagai strategi derutinisasi penanganan sampah di Kota Bandung. strategi deradikalisasi dilakukan agar proses derutinisasi sampah sebagai komoditi berjalan mulus yang didukung dengan modalitas yang sudah siap membentuk struktur baru. Ridwan Kamil ternyata sedang melakukan aplikasi teori untuk memecahkan persoalan di Bandung, dalam hal ini kaitannya dengan masalah sampah.

Jika dikaitkan dengan dimensi internal agensi, apakah pilihan ini diambil secara sadar oleh agensi atau merupakan tekanan struktural yang tidak bisa dihindari? Jawabannya bisa jadi adalah kekuatan wacana yang sangat besar. Pertarungan wacana penanganan sampah sudah menginfiltrasi kesadaran praktis agensi termasuk menstruktur menjadi motivasi tidak sadar. Sehingga setiap tindakan merupakan dorongan dari wacana-wacana yang berkembang. Bisa jadi bukan hanya wacana gentayangan yang mengendalikan tindakan Walikota, namun ada agen-agen lain yang mengkonstruksi ke-agensian Ridwan Kamil untuk maksud wacana lebih besar dibelakangnya, menjawab arti kehadiran para tim ahli dalam kepemimpinanya.

\footnotetext{
${ }^{8}$ Wawancara Ridwan Kamil soal \#205BDG dan Mimpi Bandung Juara, 26 September 2015 http://www.rappler.com/indonesia/107170wawancara-ridwan-kamil-mimpi-bandung-juara
}

\section{Sampah Bandung: Never Ending Process}

Banyak studi yang menyepakati bahwa keberadaan sampah merupakan hasil dari proses modernisasi dan industrialisasi (Pardo 1997, Moore 2006, Santoso 2006, Cooper 2009). Karena itu, wacana penanganan sampah tidak bisa lepas kaitannya dengan sistem ekonomi dan pembangunan termasuk budaya konsumsi manusia, bahkan menurut Pardo (1997), saat ini lebih tepatnya adalah waste society dibanding mass consumpted society, karena sampah menjadi masalah serius soal lingkungan dan redefinisi budaya manusia saat ini.

Menilik posisi ini, tentu kita harus melakukan refleksi atas penciptaan budaya sampah oleh manusia. Masyarakat tradisional hidup dalam lingkungan yang organis, kemudian masuk dalam fase masyarakat modern yang menemukan industri. Fase perubahan masyarkat ini bisa kita baca melalui strukturasi, dimana manusia hidup dalam tatanan ekosistem organis, semakin banyak jumlah manusia semakin besar kebutuhan hidup, merasakan keusangan rutinitas, muncul wacana modernisme untuk distribusi ekonomi, terutinisasi, terstruktur, merasakan ke usangan struktur, muncul lagi wacana perubahan, terutinisasi, dan seterusnya, hingga akhirnya muncul kesadaran tentang lingkungan yang rusak karena eksploitasi dan kehadiran sampah yang tidak bisa dihindari yang mengancam keberadaan manusia.

Sampah merupakan konsekuensi dari adanya aktifitas manusia. Setiap aktifitas manusia pasti menghasilkan buangan atau sampah. Jumlah atau volume sampah sebanding dengan tingkat konsumsi kita terhadap barang/material yang kita gunakan sehari-hari. Demikian juga dengan jenis sampah, sangat tergantung dari jenis material yang kita konsumsi. Oleh karena itu pengelolaan sampah tidak bisa lepas juga dari 'pengelolaan' gaya hidup masyrakat. Maka tawaranya adalah mengubah penanganan sampah menjadi budaya dan identitas yang baik, melalui bahasa 'manajemen' dan paradigma governance.

Banyak terdapat wacana-wacana penanganan sampah yang bertebaran, dan bisa kita lihat kecenderungannya, mana wacana dominan dan mana wacana pinggiran. Dengan pemahaman menyatu dengan alam dan tidak mengenal istilah sampah, jelas wacana ini merupakan wacanapinggiran. Hanyakelompokkelompok environmentalis fundamental yang 
akan memilih ini, begitu juga kelompok masyarakat adat yang mengisolasi diri dari dunia global yang jumlahnya sangat kecil. Sementara wacana dominan yang terbentuk bahwasaannya sampah adalah masalah. Hal ini melekat dalam kesadaran praktis diseluruh masyarakat perkotaan. Kesadaran ini dibuktikan dengan terstrukturnya sistem penanda, 'manajemen', 'menangani', dan 'mengelola'. Bahasa ini tentu saja tidak ada sebagai verba untuk sampah apabila kata sampah itu sendiri tidak pernah ada. Sekalipun dalam kasus Bandung ada upaya mewacanakan sampah adalah 'sahabat' 'yang harus disayangi dan dicintai' (menambahkan nilah pada sampah), sebenarnya ia hanya menjadi kamuflase dari maksud bahwa sampah bukan bagian integral dari tubuh manusia. Sehingga manusia dituntut memiliki kemampuan untuk berdamai dengan sampah sebagai lingkungan eksternal dirinya.

Wacana dominan yang bisa kita tangkap, berorientasi bagaimana menangani sampah secara bersih. lebih ke identitas budaya bersih, padahal sampah bukanlah antonim dari kata bersih (Moore 2006, Cooper 2099). Seharusnya pembentukan identitas atau budaya bersih merupakan counter wacana 'kotor', seperti pikiran kotor, perkataan kotor atau apapun yang bisa jadi bukan sampah. Jadi ada kerancuan berpikir antara 'kotor' dan 'sampah', yang tersrtuktur menjadi wacana dominan, entah bagaimana kemunculannya (mungkin hal ini adalah wacana soal persepsi). Keanehan ini yang bisa kita temukan dalam proses reuse dan recycle sampah atau menambah nilai lebih pada sesuatu yang disebut sampah agar bisa dianggap berguna.

Dalam penelusuran sejarah kata sampah, Cooper (2009), menemukan bahwa sampah berarti sesuatu sisa yang tidak terpakai. Sehingga tepat jika wacananya adalah membuat 'sesuatu' itu akan selalu berguna. Tapi mengapa sampah ditangani agar bersih dari pandangan mata atau menyejukkan jika dilihat, apa kaitan berguna dengan bersih (?). Wacana ini nyatanya terlestarikan untuk menjaga keseimbangan interaksi agen dan struktur dengan wacanawacana lain yang bertebaran, termasuk menjaga kelangsungan paradigma ekologi juga menjaga keberlangsungan industri kapitalis.

Pilihan yang banyak ditemukan yakni bersinergi dengan modernitas dan kapitalisasi industri. Wacana sampah dan lingkungan, memaksa industri beradaptasi dengan tuntutan yang akhirnya membuat industri berinovasi dan berstrategi menciptakan teknologi penanganan sampah atau produk yang hemat sampah (Santoso, 2006). Namun, ketergantungan manusia dengan teknologi juga tidak bisa dipisahkan karena terkait dengan distribusi ekonomi dimana sumber daya alam terbatas untuk digunakan oleh seluruh manusia. Penggunaan teknologi yang tidak bisa dihindari dan perkembangan inovasinya terus menerus akan tetap menghasilkan 'sesuatu' yang dianggap usang. Sifat 'keusangan' ujung-ujungnya adalah makna dari sampah itu sendiri (Cooper, 2009).

Dalam lingkup global, pergerakan penanganan sampah terus menerus terjadi dan berinovasi. Pilihannya adalah tertinggal atau mengikuti perkembangan inovasi pengelolaan sampah. Hal ini dialami Bandung sebagai persoalan pelik, dimana kehadiran teknologi insenerator hitung-hitungannya bisa menyelesaikan persoalan jumlah timbulan sampah di Kota Bandung. Namun insenerator dianggap kuno karena merupakan teknologi yang kadaluarsa di Negara-negara maju yang mengancam kesehatan manusia. Sementara para pegiat lingkungan diinfiltrasi oleh pengetahuan $3 \mathrm{R}$ yang memang berkembang massif di tataran civil society.

Dalam rilis terbaru Global Waste Management Outlook 2015 dari UNEP, perkembangan pengelolaan sampah sudah mencapai tahap menciptakan waste governance yang mengandalkan manajemen persampahan yang bertumpu padainstrument kebijakan yang tepat, pengaturan kelembagaan dan kapasitas kelembagaan serta mekanisme interaksi antar stakeholder guna menjadikan sampah sebagai kepentingan bersama yang bermanfaat ${ }^{9}$. Lagi-lagi bahwa radikalisasi sampah sebagai sebuah komoditi merupakan kesepakatan dan konstruksi global yang tidak bisa dihindari. Perkembangan dunia saat ini, atas nama pembangunan berkelanjutan mengharuskan sampah dikelola secara modern dengan penggunaan teknologi. Persoalannya adalah, untuk menyejajarkan posisi pengelolaan sampah di Bandung dengan pengelolaan sampah global bukan merupakan hal yang sederhana karena membutuhkan banyak prasyarat dan

\footnotetext{
${ }_{9}^{9}$ Global Waste Management Outlook 2015. United Nation Environment Programme. http://unep.org/ietc/Portals/136/Publications/Waste\%20 Management/GWMO\%20report/GWMO_report.pdf
} 
modalitas dalam menciptakan struktur penanganan sampah baru. Hal ini yang kadang disimplifikasi oleh para aktivis NGO. Sehingga, mau tidak mau penciptaan budaya tertib buang sampah menjadi relevan untuk kondisi Bandung saat ini, sekalipun tidak mampu menyelesaikan persoalan jumlah timbulan sampah yang tidak terkendali.

Mengulas kembali dalam bahasan sebelumnya, identifikasi masalah sampah di Kota Bandung ada dua yakni, soal timbulan sampah yang volumenya terus meningkat tidak berbanding lurus dengan kemampuan Pemkot serta budaya nyampah masyarakat yang masih tinggi, nyampah disini dalam arti masyarakat memilih memindahkan masalah sampahnya ke tempat lain misalnya dengan membuang sampah sembarangan ketimbang membuang sampah di tempat-tempat resmi. Alasannya bisa beragam, mulai dari tidak mau membayar iuran sampah atau di lingkungannya tidak ada tempat sampah sehingga lebih mudah di buang di pinggir jalan ataukesungai.Pokokpermasalahan inikemudian direspon berbeda oleh setiap agen yang terlibat sesuai dengan kapasitas pengetahuan yang membentuk kesadaran diskursifnya.

Bagi sebagian besar NGO pegiat lingkungan di Kota Bandung yang vokal (LPTT, YPBB dan WALHI), terdapat lima aspek yang perlu diperhatikan dalam penanganan sampah, pertama terkait dengan aspek regulasi yang bisa mendukung perubahan pengelolaan sampah di masyarakat, kedua soal aspek kelembagaan yang mana Kota Bandung mengalami persoalan nyata terkait aspek kelembagaan dalam pengelolan sampah dengan status Persahaan Daerah yang dianggap jelas berpatok pada profit, ketiga soal aspek pembiayaan yang mana selama ini Kota Bandung tidak punya alokasi yang jelas untuk pengelolaan sampah karena tidak ada SKPD yang mengakses dana tersebut, keempat soal teknis operasional mulai pengangkutan dari sumber ke TPS, TPS ke TPA, berkaitan dengan aspek kelembagaan yang tidak punya standar yang baku, dan yang kelima terkait dengan aspek partisipasi masyarakat dalam mengolah sampah $^{10}$.

Kekecewaan dari kalangan NGO terhadap pilihan cara Walikota menimbulkan interaksi struktur agen yang baru. Ketika pertama kali kehadirannya, Walikota begitu dekat dengan

\footnotetext{
${ }_{10}$ Wawancara dengan Wahyu, Ketua Bidang Advokasi WALHI Jabar, pada 24 November 2015
}

NGO dan membuka ruang komunikasi dengan para pegiat lingkungan untuk memberi masukan dan program terkait penanganan sampah. Pada saat itu, Walikota mendapat manfaat dari keberadaan NGO dengan sumber dayasumber daya pengetahuan yang dimiliki termasuk jaringan-jaringan relawan yang bisa menjadi pendukungnya. Namun seperti dijelaskan sebelumnya, pasca desakan NGO agar Walikota membuat statement resmi tidak akan membangun PLTSa, hubungan komunikasi terputus. Walikota memiliki motif tertentu dengan tidak lagi bertukar pikiran dengan para aktivis. Hal ini secara konsep disebut dengan motif, yang berhubungan langsung dengan tindakan hanya dalam keadaan yang relatif tidak lazim, situasi-situasi yang terputus dari rutinitas. Jadi, belum sempat wacana para aktivis ini terstruktur dalam kesadaran praktis Walikota melalui perjumpaan dan rutinitas tukar pendapat, dialektikanya justru diputus oleh agensi.

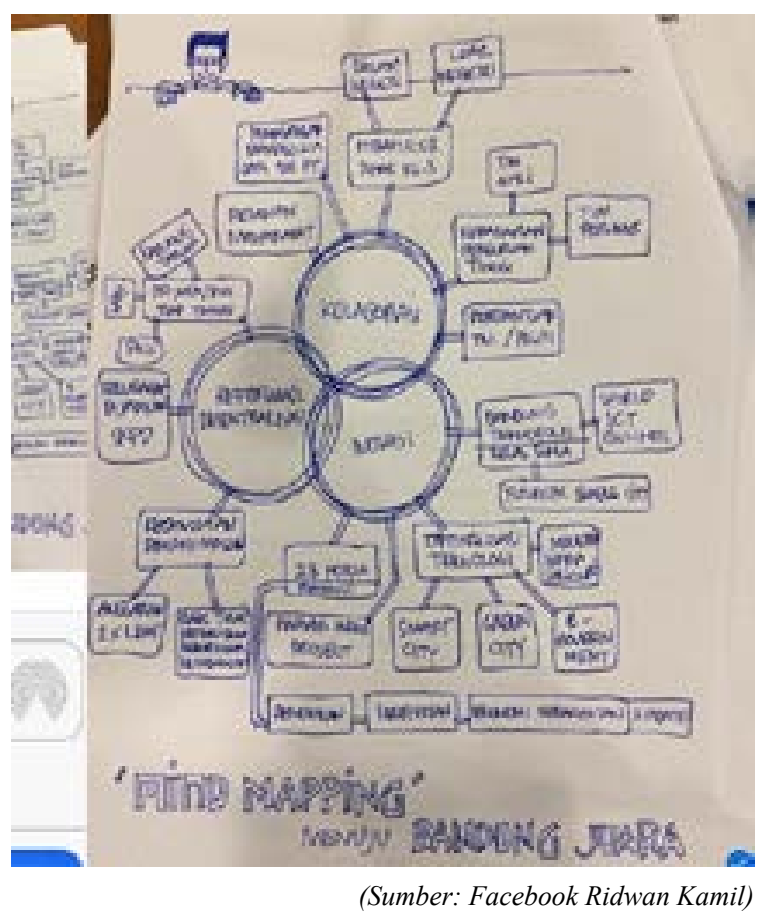

Gambar 4. Mind Mapping Strategi Menuju Bandung Juara

Melihat kejadian ini, seolah mengulang hubungan NGO dan Pemerintah Kota di masa kepemimpinan Walikota lama. Kelompokkelompok aksi lingkungan di dunia ketiga sering kali bertentangan dengan pihak pemerintah. Hal ini bukan saja ditengarai oleh merosotnyanya eko-sistem melainkan juga 'ketegangan sosial yang berasal dari dan masuk ke dalam kemerosotan itu'. Artinya, isu lingkungan di 
dunia ketiga sering terkait dengan isu ekonomi dan kekuatan sosial-politik yang lebih luas dimana mereka-mereka yang mengangkat kepentingan dengan isu lingkungan adalah mereka-mereka yang berada di luar kekuasaan (Haynes, 2000: 172). Fenomena inilah yang kemudian membuat banyak kelompok-kelompok kepentingan dengan isu-isu tertentu atas nama demokrasi dan kebebasan berpendapat sering kali bertentangan dengan konsep pembangunan yang diusung oleh pemerintah. Bagaimanapun, pola pikir Ridwan Kamil sebelum dan sesudah masuk struktur Pemerintahan akan jelas berbeda, karena ada rutinisasi struktur birokrasi yang harus ia ikuti sebagi prasyarat menggunakan Jabatan Walikota sebagai sumber daya untuk mengubah pewacanaan. Sekalipun struktur yang Ia masuki sedang dicoba untuk disiasati.

Dari sudut lain, terkait interaksi Walikota dengan birokrasi, sebelumnya Walikota sangat meminimalisir keterlibatan birokrasi dalam proyek-proyek pewacanaan sampahnya dengan membentuk Tim Bayangan. Keberadaan Tim Bayangan nyatanya mengusik identitas para birokrasi yang punya tata aturan yang harus diikuti. Kita bisa membaca bahwa kehadiran Tim Bayangan bukan malah melemahkan birokrasi tapi justru memperkuat posisi tawar birokrasi, karena segala kebijakan pemerintah akan memerlukan legitimasi dari birokrasi. Sehingga, yang awal mulanya birokrasi dipaksa 'patuh' pada bagaimanapun cara Walikota memperlakukannya, namun hubungan itu kini berubah menjadi dialektika kontrol dimana masing-masing memiliki fase kapan ia memunculkan kemandiran dan memunculkan kesaling tergantungannya. Terutama setelah dukungan NGO 'senior' lepas, maka pasukan yang bisa diandalkan adalah birokrasi itu sendiri.

Dalam hal menghadapi kendala struktural sampah diluar rekayasa sosial, Walikota justru memilih mengesampingkan penyelesaian hal tersebut. Karena dalam kendala struktural ini empat hal penting terkait regulasi, kelembagaan, pembiayaan dan teknis operasional membutuhkan sinergisitas dari banyak pihak, bukan sekedar kolaborasi.Dalamhalini, adalahsebuahkeharusan agensi untuk berinteraksi dengan institusiinstitusi politik lain di luar dirinya, bukan lagi dengan bahasa kolaborasi. Menangani kendala struktural sampah ini lah yang tidak dilakukan secara terbuka dan diinformasikan secara luas ke masyarakat seperti apa yang menjadi kebiasaannya, me-launching atau mengunggah foto-foto kegiatan. Hal ini karena ada struktur lain yang harus dihadapi yang bisa saja agensi merasa belum memiliki pilihan-pilihan startegi untuk mengatasinya.

Misalnya kita ambil contoh soal TPA. Bandung tidak punya TPA sendiri di dalam lingkungan kota karena tidak ada lagi ketersediaan lahan. Tahun 2016 pun TPA Sarimukti sudah habis masa pakainya. Sementara timbulan sampah semakin besar setiap harinya, harus dipikirkan TPAyang menjadi jalan keluar praktis sebelum merasakan keberhasilan pewacanaan sampah yang masih dibangunnya hingga saat ini. Mau tidak mau ia harus berkordinasi dengan Kepala-Kepala Daerah lainnya untuk membicarakan hal tersebut apalagi lahan yang digunakan untuk membuang sampah warga ke Bandung di lahan warga kota lain. Urusan ini memang secara formal ditangani oleh BPSR (Badan Pengelola Sampah Regional) Jawa Barat untuk mengatur sampah dari Kawasan Greater Bandung (Kota Bandung, Kota Cimahi, Kab Bandung Barat, Kab Sumedang, Kab Bandung dan Kab Garut). BPSR tentunya hanya memoderasi kesepakatan di antara daerah-daerah tersebut, karena secara otonomijelas pemilik wilayah yang sah adalah kota dan kabupaten, bukan Provinsi. Proses kesepakatan politik ini yang kemudian tidak banyak didengar rekam jejaknya, tidak seperti hingar bingar lain penanganan sampah di level masyarakat.

Dalam strukturasi, keberadaan ruang dan waktu menjadi medium upaya-upaya agensi melakukan derutinisasi. Kesadaran pentingnya dimensiruangdanwaktuharusjugadiperhatikan oleh agensi. Hal ini perlu disadari karena derutinisasi akan sulit terwujud sesuai rencana apabila dilakukan secara spasial, apalagi tidak ada modalitas yang disiapkan sebagai jembatan mereproduksi struktur baru. Sama halnya dengan keberhasilan derutinisasi penanganan sampah akan dimungkinkan berhasil apabila semua wilayah yang melingkupi Bandung melakukan hal yang sama. Ini mengantisipasi ketika terjadi perjumpaan masyarakat yang melakukan interaksi, mereka bertemu dalam frekuensi struktur yang paling tidak sama, bahwa sampah adalah masalah bersama yang harus diselesaikan dengan tanggung jawab bersama. 


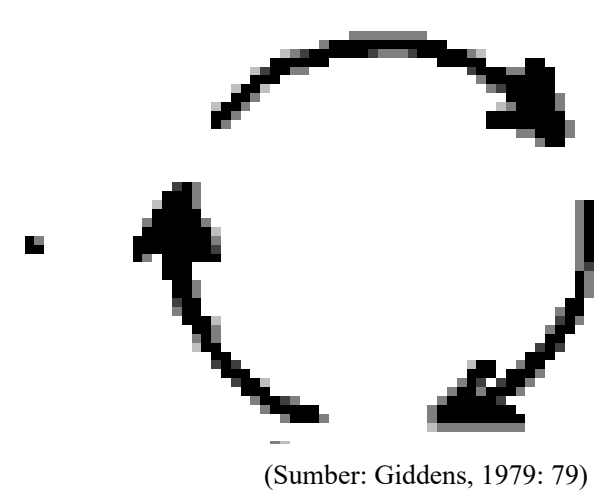

Diagram 3. Loop Strukturasi

Tetapi perlu digarisbawahi bahwa persoalan penaganan sampah dalam lingkup ruang dan spasial ini tidak hanya berbicara soal kerjasama antar daerah dalam mengelola TPA, seperti kerjasama lintas daerah Sarbagita (Denpasar, Gianyar dan Tabanan) dan Kartamantul (Yogyakarta, Sleman dan Bantul). Pengelolaan bersama TPA hanya menjadi salah satu sub sistem dalam penanganan sampah dan tidak menjadi solusi pengendalian volume sampah daerah yang semakin menumpuk. Terbukti dari stagnansi pengelolaan sampah baik oleh Sarbagita mau pun Kartamantul ${ }^{11}$. Artinya bahwa penanganan sampah bersifat sangat sistemik yang bukan hanya tentang rekayasa sosial di level individu melainkan butuh kerja ekstra untuk melakukan pembenahan di level institusional dengan penguatan kapasistas institusi serta struktur yang kondusif mulai dari aturan kebijakan yang tepat, kerangka kelembagaan, power relations, social network dan komitmen seluruh pihak terhadap good governance termasuk masyarakat dan industri (GMWO Report 2015: 186).

Dengan melihat tapak tatanan struktural yang sedang dibangun oleh Walikota terkait penanganan sampah, maka sulit untuk memberikan justifikasi soal keberhasilan derutinisasi yang dilakukan karena proses yang belum selesai, setidaknya sampai pada akhir jabatan Walikota. Strukturasi mengajak kita berpikir imbang dalam analisis institusional dan analisis

\footnotetext{
${ }^{11}$ Penanganan sampah kawasan Sarbagita merupakan mengalami kendala infrastruktur, mengingat kapasitas TPA Suwung sudah tidak mencukupi dan dampak pencemaran lingkungan juga kian mengawatirkan. Tingkat pencemaran air dan udara makin sangat parah, air lindi (leachate) yang tak dikelola dengan baik dapat mengganggu ekosistem mangrove. Sementara penanganan sampah di Kartamantul mengalami kendala dari segi program persampahan yang diterapkan di masing-masing wilayah yang berbeda. Kartamantul hanya sebatas sekber pengelolaan TPA sementara program edukasi masyarakat mengenai persampahan tidak dilakukan secara serempak. Selengkapnya lihat di http://sorotjogja.com/penanganan-sampahdas-kartamantul-perlu-perhatian-pemprov-diy/ dan http://bali.tribunnews. com/2015/02/05/wagub-bali-minta-kepala-daerah-seriusi-penanganansampah-di-sarbagita (diakses pada Jumat, 19 Februari 2016)
}

perilaku. Sehingga misalnya, justifikasi soal kebijakan yang gagal atau kepemimpinan yang populis bisa dijawab secara diskursif atas dasar keberadaan struktur yang membentuknya. Giddens mengibaratkan bahwa strukturasi merupakan a homeostatic loop, yang terus berputar parallel antara proses dan efek dalam rentang ruang dan waktu yang cukup lama. Dalam dua tahun ini, yang bisa dilihat hanya sebatas tapak tatanan struktural yang telah diciptakan dan memprediksi arah angin derutinisasi selanjutnya.

Kebertahanan tapak-tapak tatanan yang sedang dibangun ini akan diuji dalam rentang ruang waktu yang lebih kompleks di masa depan. Polanya akan selalu sama, yakni perputaran proses yang diproduksi oleh agensi dan respon yang diberikan oleh struktur. Jadi, jika ada perubahan yang terjadi soal sampah, bukan karena perubahan tersebut datang dari luar lingkaran, melainkan dari hasil interaksi wacana terus menerus antara struktur dan agensi yang menghasilkan sumber daya-sumber daya baru yang dapat digunakan untuk membangun kapasitas transformatif agensi untuk mereproduksi struktur.

Perubahan struktur hanya akan terwujud bila ada aturan dan sumber daya. Keduanya sangatpentinguntukmereproduksisistemsosial. Karena itu struktur menjelma dalam ingatan orang yang memiliki banyak pengetahuan. Dualitas struktur memberi keterangan tentang bagaimana agen dan struktur berintegrasi dan membangun identitasnya yang baru yang juga didukung oleh pengetahuan latar, ruang dan waktu yang memiliki karakteristiknya tertentu (Argyo, 2012).

\section{SIMPULAN}

Penanganan sampah yang dilakukan oleh Ridwan Kamil adalah kembali ke aspek bagaimana masyarakat Bandung memiliki kesadaran untuk tertib buang sampah dan peduli soal kebersihan. Yang terjadi, Ridwan Kamil mengesampingkan radikalisasi penanganan sampah sebagai komoditi ekonomi yang sebelumnya sudah dilakukan oleh para NGO melalui kampanye 3R maupun oleh Pemkot sendiri dengan mempertahankan keberadaan PD Kebersihan dan menghadirkan wacana pembangunan PLTSa. Ada kesadaran bahwa radikalisasi penanganan sampah yang dilakukan sebelumnya mengalami kegagalan 
dan justru banyak mendapat pertentangan dari masyarakat, sementara sampah menjadi persoalan yang tidak bisa dikendalikan. Oleh karenanya Walikota lebih memilih mengubah kebiasaan masyarakat membuang sampah, hal yang terlihat sangat sederhana dan tidak menyelesaikan soal timbulan sampah di Bandung yang terus meningkat, namun aspek ini yang lebih diterima oleh masyarakat terlepas dari skeptisme dan kritik para pegiat lingkungan. Hal ini menandai bahwa derutinisasi akan sulit terwujud apabila agensi melakukan lompatan signifikansi tanpa terlebih dahulu menyiapkan modalitas sebagai sarana membakukan gagasan baru dalam benak masyarakat. Sementara Ridwan Kamil melakukan derutinisasi dengan cara merambat, yakni dengan strategi deradikalisai semu demi tercapainya tujuan derutinisasi kebiasaan membuang sampah sembarangan dengan membangun rasa kepedulian dan tanggung jawab untuk bersama-sama menciptakan kota bersih.

Setidaknya ada dua hal yang bisa dipelajari dari cerita penelitian ini: Pertama, strukturasi sendiri merupakan teori yang kompleks. Uji coba penerapan teori ini membutuhkan banyak prasyarat kondisi yang harus dipersiapkan apa bila reproduksi struktur itu benar-benar terjadi. Dalam kasus penanganan sampah di Bandung, didapati banyak lompatan-lompatan alur yang mengakibatkan tidak terstrukturnya gagasan baru. Hal ini karena prasyarat modalitas sebagai sarana mengubah interaksi menjadi sebuah struktur belum terpenuhi.

Kedua, sampah sendiri merupakan sebuah entitas yang multidimensional. Seperti dikatakan Pardo (1997) bahwa cara penanganan sampah menjadi redefinisi budaya dan identitas sebuah masyarakat. Meski demikian, tidak mudah mengubah cara pandang masyarakat terhadap sampah karena sampah saat ini sudah masuk ke dalam arena politik dimana banyak kepentingan berkontestasi. Sehingga kalau hanya Bandung yang berusaha melakukan derutinisasi sampah menjadi hal yang sulit dan dibutuhkan waktu yang sangat lama karena banyak struktur yang terlibat dalam praktik sosial yang terjadi yang dibawa oleh masyarakat lain di luar wilayah Bandung. Artinya ditegaskan bahwa derutinisasi sampah tidak bisa dilakukan secara spasial dan parsial kalau bukan hanya sekedar perubahan artifisial. Bandung menjadi sebuah prototype bahwa derutinisasi penanganan sampah harus menjadi agenda nasional untuk mencapai perubahan pengelolaan sampah yang lebih baik. Jika tidak, maka Indonesia akan selalu dilekati predikat Negara berkembang yang tidak bisa mengubah tantangan sampah menjadi sebuah berkah, terlebih lagi Indonesia hanya akan selalu menjadi objek para Negara pendonor proyek sustainable development yang menjadi pemicu kekacauan tatanan struktur yang belum siap seperti yang dialami Bandung lewat Bandung Urban Development Project-nya di tahun 1985.

\section{DAFTAR PUSTAKA}

"Persoalan Sampah Makin Menghantui". Majalah Swara Bina Kota. Edisi 1/2014, hal 40-41.

"Hari Lingkungan Hidup Ditandai dengan GPS', Majalah Swara Bina Kota Bandung Juara, Edisi 3/2014.

Damanhuri, Enri. 2007. "Trend Global dalam Pengelolaan Sampah Kota". Makalah seminar pada Symposium Pengembangan Surabaya Metropolitan Area di Masa Depan -Sub Topik Manajemen Sampah Kota, 50 tahun Jurusan Teknik Sipil ITS, Surabaya, 23-11-2007.

Giddens, Anthony. 1979. Central Problems in Social Theory-Action, Structure and Contradiction in Social Analysis. Berkeley and Los Angeles : University of California Press.

2010. Teori Strukturasi (Terjemahan). Yogyakarta: Pustaka Pelajar.

Haryanto. 2009. "Elit Politik Lokal dalam Perubahan Sistem Politik". Jurnal Ilmu Sosial dan Ilmu Politik, Vol. 13, No. 3, November 2009, hal 131-148. (Available at: http://jurnalsospol.fisipol.ugm.ac.id/ index.php/jsp/article/view/70/61)

Marsh, David dan Stoker, Gerry. 2011. Teori dan Metodi dalam Ilmu Politik (Terjemahan). Bandung : Nusa Media

Nashir, Haedar. 2012. "Memahami Strukturasi Dalam Perspektif Sosiologi Giddens". Jurnal Sosiologi Reflektif, Vol. 7, No.1, Oktober 2012. 
Pardo, Mercedes. 1997. "The Waste Society: Some Elements For A Social Theory Of Waste In Modern Societies". Available on http://e-archivo.uc3m.es/bitstream/ handle/10016/3129/The-Waste-Society. pdf? sequence $=1$ (diakses pada hari Sabtu, 7 November 2015)

Ritzer, George dan Goodman, Douglas J. 2004. Teori Sosiologi Modern (Terjemahan). Jakarta : Prenada Media.

Santoso, Purwo. 2006. "Radikalisasi Pengelolaan Sampah". Jurnal Balairung UGM Edisi 39/XX/2006.

. 2012. "Transformasi Wacana Dan Praksis Politik Lingkungan". Diakses dari: http://www.academia. edu/2205555/TRANSFORMASI_ WACANA DAN

Dokumen Masterplan Persampahan Kota Bandung (2014). BPLH Kota Bandung.

Dokumen Non Fisik Adipura Kota Bandung 2013-2014

Dokumen Non Fisik Adipura Kota Bandung 2014-2015
Dokumen RPJMD Kota Bandung 2013-201

Dokumen Final Report Gerakan Sejuta Biopori

Global Waste Management Outlook. 2015. United Nation Environment Programme. http://unep.org/ietc/Portals/136/ Publications/Waste\%20Management/ GWMO\%20report/GWMO_report.pdf

Guidelines For National Waste Management Strategy- Moving From Challenges to Opportunities. 2013. United Nation Environment Programme. http://www. unep.org/ietc/Portals/136/Publications/ Waste $\% 20$ Management/UNEP $\% 20$ NWMS\%20English.pdf

http://venusgotgonorrhea.wordpress. com/2014/01/16/bandung-the-cityof-pigs/ (diakses pada hari Senin, 29 September 2014)

http://www.rappler.com/indonesia/107170wawancara-ridwan-kamil-mimpibandung-juara (diakses pada hari Kamis, 10 Desember 2015) 